How to cite this article:

Jali, M. N., Deraman, R., Ahmad Shauri, N. A., Samsudin, S., Abdol Ghafar, F., Khairuddin, K. S. (2020), The relationship between strategic knowledge management processes and social innovation, Journal of Business Management and Accounting, 10(2), 1-13.

\title{
The Relationship between Strategic Knowledge Management Processes and Social Innovation
}

\author{
Muhamad Nizam Jali*, Rosmawati Deraman, \\ Noor Azura Ahmad Shauri, Suzany Samsudin, Farha Abdol Ghapar \\ \& Khairun Syafiza Khairuddin \\ Kolej Universiti Poly-Tech MARA (KUPTM), Kuala Lumpur
}

Received: $18 / 5 / 2020$

Revised: $17 / 8 / 2020$

Accepted: $27 / 8 / 2020$

Published: 15/11/2020

\begin{abstract}
Social Innovation has been considered as the main policy agenda in various developed countries throughout the world. Social Innovation is said to make a massive contribution to the social, economic and technological progress of nations. Therefore, it addresses critical issues, among which are poor economic growth, massive unemployment, poor social health, poor living conditions, poor education systems and poor technological advancement. The aim of this paper is to present an empirical insight on the impact of social innovation on strategic knowledge management processes i.e. knowledge creation, knowledge transfers and knowledge application. The main data for this study was collected through survey questionnaires via personally administered and email from 200 project leaders of Majlis Amanah Rakyat (MARA) education institutionsindustry-community partnership project. The data were collected from December 2018 till December 2019. The data was analyzed using SPSS version 19. The findings indicate a significant positive relationship between strategic knowledge management processes i.e. knowledge creation, knowledge transfer and knowledge application and social innovation.
\end{abstract}

Keywords: Social innovation, knowledge creation, knowledge transfer, knowledge application.

* Corresponding Author

E-mail: nizam@kuptm.edu.my 


\subsection{Introduction}

Social Innovation has become a new strategy which has received an overwhelming interest from many governments, public and private institutions worldwide (Pue et.al., 2015). Various developed countries namely the United States (US), United Kingdom (UK) and some wealthy European Union (EU) countries have outlined social innovation as their new strategy due to the fact that the contribution of social innovation is said to be much significant as compared to technological innovation per se (Altuna et.al., 2015; Benneworth \& Cunha, 2015). According to Lizuka, (2013), social innovation gives concurrent benefits in terms of social, economic and technological aspects whereas technological innovation limitedly contributes to merely fulfilling private needs. In line with the above statements, the Malaysian government has also taken initiatives in relation to social innovation with the rest of the world. Social innovation as a new innovation outcome strategy has been addressed in the 12 Malaysian Plan (RMK-12). The aforementioned plan is regarded as the major strategy in helping the Malaysian government to achieved its main aspiration of becoming a high income country status by the year 2025. The inclusion of social innovation as a new innovation strategy is meant to propel Malaysia to attain economic empowerment sustainability and social re-engineering. Like many developed countries, Malaysia also embarked on social innovation as its new strategy through university-industry-community partnership. This is due to the fact that the university is seen as a potential source of new knowledge for innovation, economic growth and competitiveness and direct relationships between university-industry-community can bring massive contribution to the nation as a whole (Breznitz \& Ram, 2013).

To elaborate further, the new superior knowledge that is created within the partnership ecosystem through the independent processes of knowledge creation, knowledge transfers and knowledge application is then embedded into products, processes and services which in turn produce highly innovative products, processes and services that contribute towards social, economic and technological payoffs (Kanter, 2015). In addition, this in turn, provides a significant return in terms of better living condition of people's, better environmental condition, better education, better human development, sustainable economic growth, increased employment opportunities and contributes towards profit maximization and private needs (Altuna et.al., 2015).

The statements from the above paragraphs is very much in line with the two underpinning theories, Resource Based View (RBV) and Knowledge Based View (KBV). Based on both theories, it is identified that the value, rarity, inimitability and lack of substitutes (Barney, 1991) of intangible resources is referred to knowledge resource (James (2004). Knowledge resource has emerged as the valuable, rare, inimitable and nonsubstitutable resources which can lead to unique solutions and value creation of innovation and sustainable competitive advantage (Nonaka \& Takeuchi, 1995; Miller, 
2012). This assumption is based on changes in business environment, technological change, competition and globalization which ensure that organizations are dynamic and be able to adapt to the rapid changes of new economic environment (Abou-Zeid, 2005; Hamel \& Prahalad, 2013). Moreover, in today's new era of knowledge led economy, the concept of innovation considers knowledge resource as the new basis for innovation and replacing old tangible resource that refers to raw materials, money and machinery (Alegre \& Chiva, 2008; Sammarra \& Biggiero, 2008). Specifically, knowledge resource is created through the integrated and independent processes of knowledge creation, knowledge transfers and knowledge application and it involved the interplay of tacit and explicit knowledge (Meier, 2011). Furthermore, it is embedded into products, processes and services to make them highly innovative and in turn contribute not only towards technological but also towards social and economic benefits (Lichtenthaler \& Lichtenthaler, 2009; Chiva et.al., 2014). Krlev et.al., (2014) asserts the knowledge resource is proven more effective and efficient as compared to the tangible resource i.e. raw materials, monetary and machinery, in order to improve the use of assets and resources. A recent study by Unceta et.al., (2016) found that a linkage between superior knowledge resource and social innovation is the best possible solution in producing superior products, processes and services to overcome social, economic and technological problems.

From the above paragraphs, various researchers maintained that social innovation as a new innovation strategy is very much under-developed, limited and inconsistent in terms of empirical evidence offered within the social innovation literature (CajaibaSantana, 2014; Krlev, et.al., 2014; Makimattila et.al., 2015). This situation perhaps offers all parties concern a limited alternative in searching for best practice references in regards to adopting social innovation as a new innovation strategy. To elaborate further, within the literature, social innovation is very much central and exclusively connected to the social aspects and social purposes and it is distinct from any other innovation outcomes, for example technological driven innovation (Dawson \& Daniel, 2010). This situation leaves social innovation isolated within the scope of social and creates under-value and under-investment of social innovation (Pol \& Ville, 2009; Altuna et.al., 2015).

Social innovation is not necessarily tied up to address specific social purposes but its significant value encompasses wide range of benefits that includes social, economic and technological aspects (Dunphy et.al., 2007; Unceta et.al., 2016). Furthermore, social innovation has been recognized as a new innovation strategy by countries including the United Kingdom, the United States of America, the Netherlands, France, Belgium, Germany and some Asian countries, for example, Malaysia. Bitzer and Hamann (2015) highlighted only recently that social innovation has been adopted by countries in order to add value to existing social purposes approach in order to meet demands in a new knowledge led economic environment and also because of the massive recognition 
given by the various governments and policy makers worldwide. Despite the integration of economic and technological aspects within the outcome of social innovation, recent studies of social innovation are predominantly focused on the conceptual part rather than give useful empirical insight on how social innovation as an outcome contributes towards social, economic and technological aspect (Lizuka, 2013; Krlev et.al., 2014). Furthermore, little research has examined social innovation with strategic knowledge management processes particularly in the context of university-industry-community partnership in creating superior knowledge resource (Benneworth \& Cunha 2015). Westley, et.al., (2014) highlight that there is an urgent need for comprehensive overview and analysis on the empirical evidence of social innovation and strategic knowledge management processes. In addition, a complete and extensive understanding of how social innovation and strategic knowledge management processes is linked and connected across organizations must be seriously investigated (Battisti, 2012). Hence, social innovation and its association with strategic knowledge management processes i.e. knowledge creation, knowledge transfer and knowledge application, must be seriously explored so that researchers can provide feedbacks and recommendations to all stakeholders and actors within the Malaysian university-industry-community partnership ecosystem given the massive contribution that it might make towards the nations' core aspirations.

This paper examines the relationship between strategic knowledge management processes represented by knowledge creation, knowledge transfers and knowledge application used as the independent variables and their influence on social innovation which is the dependent variable in the context of MARA education institutionsindustry-community partnership project ecosystems. This is meant to provide feedback and recommendations to all stakeholders involved in MARA education ecosystem.

\subsection{Proposed Conceptual Framework}

According to the framework, social innovation is the dependent variable of the study. Strategic knowledge management processes are represented by knowledge creation, knowledge transfer and knowledge applications which are the independent variables of this study. The study focussed on the direct relationship between each dimension of independent and dependent variables. Within the literature, social innovation is defined as changing a system by developing novel solutions in border spanning communities i.e. university-industry-community partnership to create social value and promote community development through strategic knowledge management activities (Benneworth and Cunha, 2015). Knowledge creation is regarded as a fundamental process of strategic knowledge management in which individuals create new knowledge resource in order to apply to organization products, processes and services (Nonaka \& Von Krogh, 2009). Kumar and Ganesh (2009) see knowledge transfer as an activity 
that specifically refers to exchanging two knowledge resource i.e. tacit and explicit knowledge between the two agents. The two agents refer to the individuals, team or an organization (Joshi et.al., 2007). Song et.al., (2005) explains knowledge application as a timely response to technological change by applying new knowledge resource to new products, processes and services.

There is substantial amount of conceptual and empirical research within the literature highlighting the significant relationship between strategic knowledge management and technological driven innovation. However, social innovation is very much underdeveloped and received little attention in associations with strategic knowledge management processes (Cajaiba-Santana, 2014; Krlev, et.al., 2014; Makimattila et.al., 2015). Furthermore, very little research has examined social innovation with strategic knowledge management activities, particularly in the context of university-industrycommunity partnership (Benneworth \& Cunha 2015). In addition, previous studies within the scope of social innovation mainly focus on pure social aspects. Therefore, this study considers social innovation as the dependent variable in order to investigate its relationship with strategic knowledge management processes. Based on the RBV and KBV theories, valuable, rareness, inimitable and lack of substitutes of knowledge resources and capabilities are the important source of social innovation and sustainable competitive advantage. Strategic knowledge management processes represented by knowledge creation, knowledge transfer and knowledge application are used as the independent variables to test their impact on social innovation i.e. dependent variable, in the context of Malaysian university-industry-community partnership ecosystem. Figure 1 below illustrate the proposed framework of variables in this paper.

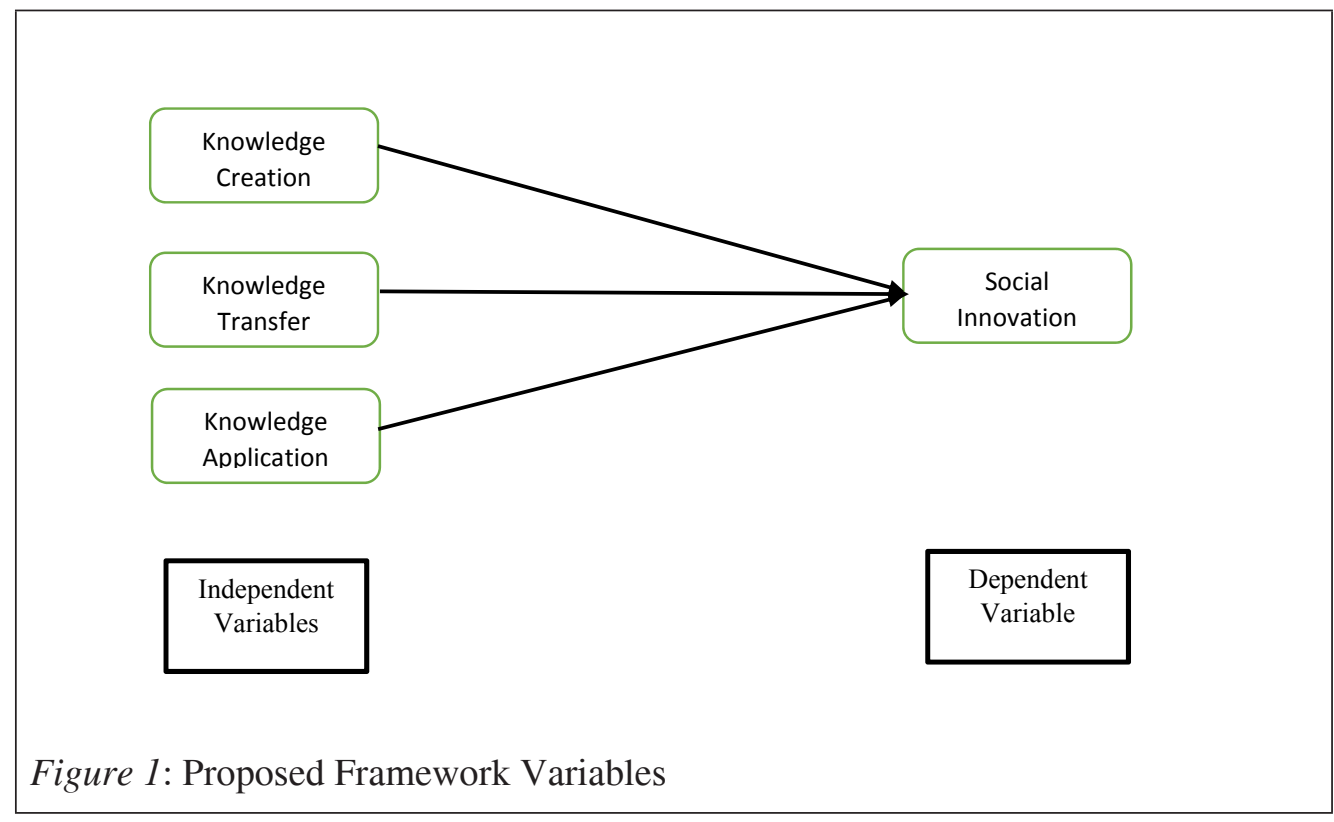




\subsection{Research Design}

Research design is described as the detailed plan for a study that includes data collection method, samples, data analysis and the results (Kumar et.al., 2013). According to Saunders et.al., (2007), a research design is a master plan and procedures of how the researcher will go about answering the questions under investigation that have been set earlier. This paper used the quantitative design in order to present an empirical insight on the impact of strategic knowledge management processes namely: Knowledge Creation, Knowledge Transfer and Knowledge Application on social innovation. This paper utilized correlation and regression analysis. A quantitative approach is regarded as a systematic empirical technique that generates statistical and mathematical data for analysis (Bryman \& Bell, 2015) and will helps researchers to determine a scientific relationship between two variables under study (Kumar et.al., 2013). The unit of analysis of this study are the project leaders involved in the MARA university-industrycommunity partnership project. A sample of 200 respondents provided feedback. They consist of project leaders from MARA education institutions. This study used structured questionnaires as the medium of collecting data from the respondents (Creswell, 2003).

\subsection{Data Collection}

The data collection method used in this study is structured questionnaire. The purpose of using the structured questionnaires is to examine the relationship between strategic knowledge management processes i.e. knowledge creation, knowledge transfers and knowledge application and social innovation within the MARA university-industrycommunity partnership projects. According to Sekaran (2003), self-administered approach is the best way in collecting data through structured questionnaires. This study used personal and internet surveys in distributing the structured questionnaires to the target respondents. Personal approach is through face to face distribution of the questionnaires. It has the advantage of getting complete answers to the questionnaires within a short period of time and also can clarify any doubt that arises immediately (Kumar et.al., 2013). Furthermore, this study used the internet survey through emails to reach respondents who live in remote areas because it is less expensive with faster transmission time (Hair, et.al., 2007). The population of this study comprised of all 200 respondents ( 200 projects X 1 project leaders representing each project) who answered the structured questionnaires distributed by the researchers of this study. This study chose project leaders because they are versed in terms of information about the project and they play a leading role within the project. The questionnaire was distributed to the target respondents from the period of December 2018 until December 2019.

\subsection{Samples}

In general, population $(\mathrm{N})$ refers to the entire group of people, events, projects or things that the researchers want to investigates (Kumar et.al., 2013). Furthermore, sampling 
(n) is part of the population or selecting adequate amount of people, events, projects or things from the population (Sekaran, 2003). This study investigates the relationship between strategic knowledge management processes namely, knowledge creation, knowledge transfers and knowledge application and social innovation. Thus, all 200 respondents participated in answering the structured questionnaires distributed and this is well justified (Kumar et.al., 2013).

\subsection{Data Analysis and Results}

The aim of this paper is to provide an empirical insight on the relationship between strategic knowledge management i.e. Knowledge Creation, Knowledge Transfer, Knowledge Application and Social Innovation. The paper investigated Social Innovation as the dependent variable and Knowledge Creation, Knowledge Transfer and Knowledge Application as independent variables. A set of questions were developed for both variables. Social Innovation is represented by 17 items adapted from previous studies among which are De kok et.al., (2014) and Sanzo Perez et.al. (2015). Knowledge creation was measured using 16 questionnaires adapted from past studies by Popadiuk \& Choo, (2006) and Von Krogh et.al., (2012). Knowledge transfer was measured using 10 items adapted from previous studies by Cegarra-Navarro et.al., (2014) and Wensley \& Cegarra-Navarro (2015) while Knowledge application was measured by 11 items adapted from previous studies by Camison \& Fores, (2010) and Cepeda-Carrion et.al., (2012).

The paper analysed the quantitative data using the SPSS software version 19. The analysis comprises of data screening procedures which involved detection of missing data, outliers and non-response bias. Furthermore, the paper performed descriptive analysis, reliability and validity analysis, t-test analysis, assumptions of multiple regression which involves normality test, linearity test, homoscedasticity test, multicollinearity test followed by correlation and multiple regressions analysis.

\subsection{Findings from Correlation Analysis}

In order to identify the factors that have an association with social innovation, correlation analysis was conducted. The correlation coefficient indicate the relationship between the independent and dependent variables. According Hair et. al., (2006), the number representing the Pearson correlation is referred to as a correlation coefficient. It ranges from -1.00 to +1.00 , with zero representing absolutely no association between the two metric variables. The larger the correlation coefficient the stronger the linkage or level of association. A strong correlation is represented by a coefficient exceeding the value of 0.5 whereas a medium or modest correlation is when the coefficient has a value of between 0.5 and 0.2 . Any coefficient possessing a value less than 0.2 will be deemed 
as showing a weak correlation. Benny and Feldman (1985) suggested a rule of thumb, that the correlation coefficients that exceed 0.8 (very strong correlation) will likely to result in multi-colinearity. Cohen (1988) has put forward a guideline on the effect sizes of the correlation coefficients in social science studies as: small effect size, $r=0.1-$ 0.29 , medium: $r=0.30-0.49$, and large: $r=0.50$. Result of correlation analysis can be found in Table 1 below:

Table 1

Result of Correlation Analysis

Correlation analysis of Social Innovation and Strategic Knowledge Management processes

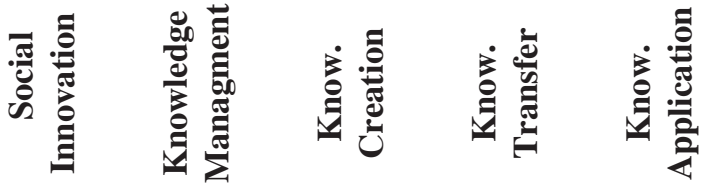

\begin{tabular}{llllll}
\hline Social Innovation & 1 & & & & \\
SKM & $.600^{* *}$ & 1 & & & \\
Knowledge Creation & $.484^{* *}$ & $.638^{* *}$ & 1 & & \\
Knowledge Transfer & $.325^{* * *}$ & $.680^{* *}$ & -.022 & 1 & \\
Knowledge Application & $.301^{* *}$ & $.625^{* *}$ & -.066 & $.567^{* *}$ & 1 \\
\hline
\end{tabular}

Notes: $* * \mathrm{p}<0.01,{ }^{*} \mathrm{p}<0.05$

Table 1 above show the results of correlations analysis to determine the relationship between social innovation and strategic knowledge management processes as found in this study. It was found that overall, social innovation is significantly associated with strategic knowledge management processes $(r=0.600, p<0.01)$. It was also found that social innovation has a significant relationship with Knowledge Creation ( $\mathrm{r}=0.484$, $\mathrm{p}<0.01)$, with Knowledge Transfer $(\mathrm{r}=0.325, \mathrm{p}<0.01)$ and with Knowledge Application $(\mathrm{r}=0.301, \mathrm{p}<0.01)$.

\subsection{Findings from Regression Analysis}

The main objectives of this paper is to examine the relationship between strategic knowledge management processes i.e. knowledge creation, knowledge transfer and knowledge application and social innovation within the context of Malaysian university-industry-community partnership ecosystem. Hence, this paper developed the regression model to be tested. The dependent variable of this study is social innovation. 
Moreover, this study proposed three main independent variables i.e. knowledge creation, knowledge transfers and knowledge application.

The regression model tested the effect of knowledge creation, knowledge transfer and knowledge application on social innovation. The results of regression analysis are as shown in Table 2 below. It can be seen that knowledge creation, knowledge transfer and knowledge application explained 63.8 percent of social innovation $\left(\mathrm{R}^{2}=0.638 \mathrm{~F}=33.015\right.$, $\mathrm{p}<0.01)$. Knowledge Creation has significantly predicted Social Innovation $(\mathrm{B}=0.204$, $\mathrm{t}=4.120, \mathrm{p}<0.01)$. Next, knowledge transfers and knowledge application successfully predicted workplace innovation as follows: Knowledge Transfer $(B=0.094, t=2.263$, $\mathrm{p}<0.05)$ and $(\mathrm{B}=0.184, \mathrm{t}=2.507, \mathrm{p}<0.05)$.

Social Innovation $=0.472+0.204 \mathrm{Crea}_{\mathrm{i}}+0.094 \mathrm{Trans}_{\mathrm{i}}+0.184 \mathrm{Appli}_{\mathrm{i}}+\overline{\mathrm{e}}$

Table 2

Effect of Knowledge Creation, Knowledge Transfer and Knowledge Application on Social Innovation

\begin{tabular}{lccc}
\hline & B & T & Sig. \\
\hline Knowledge Creation & .204 & 4.120 & $.000^{* *}$ \\
Knowledge Transfer & .094 & 2.263 & $.045^{*}$ \\
Knowledge Application & .184 & 2.507 & $.033^{*}$ \\
$\mathrm{R}^{2}$ & 0.638 & & \\
$\mathrm{~F}$ & 33.015 & & \\
Sig. & 0.000 & & \\
\hline
\end{tabular}

Notes: $* * \mathrm{p}<0.01 ; * \mathrm{p}<0.05$

\subsection{Conclusion and Discussion}

This paper's outputs provide an ideas and solutions for MARA University-IndustryCommunity actors to work together in an effective an efficient way within their partnership projects. The paper's outcomes also give a better understanding to actors in MARA University-Industry-Community partnership projects on the relationship between social innovation and strategic knowledge management processes. This in turn adds value to the existing policy and statutory initiatives concerning on MARA University-Industry-Community partnership projects and future initiatives.

The results of correlation and regression revealed that knowledge creation have a positive relationship with social innovation. This finding is consistent with past studies 
(Nonaka et.al.2000). Tacit and explicit knowledge can be used as a new solution in creating a highly innovative product, processes and services which can ensure significant benefit towards social, economic and technological development. Furthermore, the results of regression analysis between knowledge transfer and social innovation in the context of MARA education institutions-industry-community partnership project ecosystem revealed a strong positive relationship with social innovation. This is consistent with the literature and past studies by Flatten et.al., (2011); Plewa et.al., (2013) that effective communication and transformation between all actors within the MARA education institutions-industry-community partnership project have a significant impact on the transfer process of new knowledge resource which can be used as a new solution in creating highly innovative products, processes and services. This can also provide significant benefits towards social, economic and technological aspects in a concurrent way. The results of correlation and regression of knowledge application and social innovation in the context of MARA education institutionsindustry-community partnership project revealed that knowledge application have a positive relationship with social innovation. This is consistent with the past studies by Bierly et.al., (2009); Lichtenthaler, (2009) on the significant impact of application of knowledge on developing and refining existing products, processes and services through superior knowledge resource which subsequently have a significant outcome on social, economic and technological development.

\section{Acknowledgement}

The authors would like to thank the anonymous reviewers. The authors would also like to give special thanks to the Research Management Centre KUPTM secretariat for the funding received for this research.

\section{References}

Abou-Zeid, E. S. (2005). A culturally aware model of inter-organizational knowledge transfer. Knowledge Management Research \& Practice, 3(3), 146-155.

Alegre, J., \& Chiva, R. (2008). Assessing the impact of organizational learning capability on product innovation performance: An empirical test. Technovation, 28(6), 315-326.

Altuna, N., Contri, A. M., Dell Era, C., Frattini, F., \& Maccarrone, P. (2015). Managing social innovation in for-profit organizations: the case of Intesa Sanpaolo. European Journal of Innovation Management, 18(2), 258-280.

Barney, J. B. (1991). Firm resources and sustained competitive advantage. Journal of Management, 17(1), 99-120. 
Battisti, S. (2012). Social innovation: The process development of knowledge-intensive companies. International Journal of Services Technology and Management, 18(3-4), 224-244.

Bierly, P. E., Damanpour, F., \& Santoro, M. D. (2009). The application of external knowledge: Organizational conditions for exploration and exploitation. Journal of Management Studies, 46(3), 481-509.

Bryman, A., \& Bell, E. (2015). Business research methods. Oxford University Press. USA.

Benneworth, P., \& Cunha, J. (2015). Universities contributions to social innovation: Reflections in theory \& practice. European Journal of Innovation Management, 18(4), 508-527.

Breznitz, S. M., \& Ram, N. (2013). Enhancing economic growth? University technology commercialization. Creating Competitiveness: Entrepreneurship and Innovation Policies for Growth: Edward Elgar Publishing, 88-115.

Cajaiba-Santana, G. (2014). Social innovation: Moving the field forward. A conceptual framework. Technological Forecasting and Social Change, 82, 42-51.

Camison, C., \& Fores, B. (2010). Knowledge absorptive capacity: New insights for its conceptualization and measurement. Journal of Business Research, 63(7), 707-715.

Cepeda Carrion, G., Cegarra Navarro, J. G., \& Jimenez Jimenez, D. (2012). The effect of absorptive capacity on innovativeness: Context and information systems capability as catalysts. British Journal of Management, 23(1), 110-129.

Cegarra-Navarro, J. G., Eldridge, S., \& Wensley, A. K. (2014). Counter-knowledge and realised absorptive capacity. European Management Journal, 32(2), 165176.

Chiva, R., Ghauri, P., \& Alegre, J. (2014). Organizational learning, innovation and internationalization: A complex system model. British Journal of Management, 25(4), 687-705.

Creswell, J. W. (2003). Research Design: Qualitative. Quantitative and Mixed Methods Approaches, 2nd Edition. London, UK: Sage Publications.

Dawson, P., \& Daniel, L. (2010). Understanding social innovation: A provisional framework. International Journal of Technology Management, 51(1), 9-21.

De Kok, J., Doove, S., Oeij, P., \& Kraan, K. (2014). Scale effects in workplace innovations. EIM Business and Policy Research.

Dunphy, D., Griffiths, A. \& Benn, S. (2007). Organizational Change for Corporate Sustainability. 2nd ed. Routeledge, London.

Flatten, T. C., Engelen, A., Zahra, S. A., \& Brettel, M. (2011). A measure of absorptive capacity: Scale development and validation. European Management Journal, 29(2), 98-116.

Hair, J. F., Black, W. C., Babin, B. J., Anderson, R. E., \& Tatham, R. L. (2006): Multivariate Data Analysis. Upper Saddle River. Auflage. 
Hair, J. F., Money, A. H., Samouel, P., \& Page, M. (2007). Research Methods for Business (1st ed.). John Wiley \& Son Ltd. Sussex, England.

Hamel, G., \& Prahalad, C. K. (2013). Competing for the Future. Harvard Business Review, 72(4), 122-128.

Krlev, G., Bund, E., \& Mildenberger, G. (2014). Measuring what matters-Indicators of social innovativeness on the national level. Information Systems Management, 31(3), 200-224.

Kumar, M., Talib, S. A., \& Ramayah, T. (2013). Business research methods. Oxford Fajar/Oxford University Press.

Kanter, R. M. (2013). Jobs and Social Innovation. Standford Social Innovation Review, 11(2), 34-36.

Lichtenthaler, U. (2009). Absorptive capacity, environmental turbulence, and the complementarity of organizational learning processes. Academy of Management Journal, 52(4), 822-846.

Lichtenthaler, U., \& Lichtenthaler, E. (2009). A capability-based framework for open innovation: Complementing absorptive capacity. Journal of Management Studies, 46(8), 1315-1338.

Lizuka, M. (2013). Innovation systems framework: Still useful in the new global context?. UNU-MERIT. Working paper series United Nations. Maastricht, The Netherlands Innovation, 005.

Makimattila, M., Junell, T., \& Rantala, T. (2015). Developing collaboration structures for university-industry interaction and innovations. European Journal of Innovation Management, 18(4), 451-470.

Nonaka, I. \& Takeuchi, H. (1995). The knowledge creating company: How Japanese companies create the dynamics of innovation. Oxford University Press, p. 284, ISBN 978-0-19-509269-1. New York: USA.

Meier, M. (2011). Knowledge management in strategic alliances: A review of empirical evidence. International Journal of Management Reviews, 13(1), 1-23.

Miller, K. (2012). Exploring the knowledge processes within university technology transfer: through and absorptive capacity lens. Unpublished Phd thesis. Ulster University. Northern Ireland. UK.

Plewa, C., Korff, N., Johnson, C., Macpherson, G., Baaken, T., \& Rampersad, G. C. (2013). The evolution of university-industry linkages-A framework. Journal of Engineering and Technology Management, 30(1), 21-44.

Pol, E., \& Ville, S. (2009). Social innovation: Buzz word or enduring term?. The Journal of Socio-Economics, 38(6), 878-885.

Popadiuk, S., \& Choo, C. W. (2006). Innovation and knowledge creation: How are these concepts related?. International Journal of Information Management, 26(4), 302-312.

Sammarra, A., \& Biggiero, L. (2008). Heterogeneity and specificity of InternFirm knowledge flows in innovation networks. Journal of Management Studies, 45(4), 800-829. 
Sanzo-Perez, M. J., Alvarez-Gonzalez, L. I., \& Rey-Garcia, M. (2015). How to encourage social innovations: a resource-based approach. The Service Industries Journal, 35(7-8), 430-447.

Saunders, M., Lewis, P. \& Thornhill, A. (2007) Research methods for business students. 4th edition. Harlow: Prentice Hall.

Sekaran, U. (2003). Research method for business: A skill Approach. New Jersey: John Willey and Sons, Inc.

Unceta, A., Castro-Spila, J., \& Garcia Fronti, J. (2016). Social innovation indicators. Innovation: The European Journal of Social Science Research, 1-13.

Von Krogh, G., Nonaka, I., \& Rechsteiner, L. (2012). Leadership in organizational knowledge creation: A review and framework. Journal of Management Studies, 49(1), 240-277.

Wensley, A. K., \& Navarro, J. G. C. (2015). Overcoming knowledge loss through the utilization of an unlearning context. Journal of Business Research, 68(7), 15631569. 